Int. J. Morphol.,

29(3):678-680, 2011

\title{
The Effects of Cadmium Chloride on the Oesophagus of Rats
}

\author{
Efecto del Cloruro de Cadmio sobre el Esófago de Ratas
}

"Deveci, E \& **Deveci, $\mathbf{S}$.

DEVECI, E. \& DEVECI, S. The effects of cadmium chloride on the oesophagus of rats. Int. J. Morphol., 29(3):678-680, 2011.

SUMMARY: Cadmium Chloride $(\mathrm{CdC} 1)$ is a teratogen which is commonly used in industry. Although it is well known to cause toxicity in testes, kidney, heart and liver, few studies have been carried out in the digestive system. In the present study the effects of $\mathrm{CdC} 1$ on the esophagus of rats were investigated Wistar albino rats weighing 180-200 g were used. The animals were divided into two groups; one group was administered $2 \mathrm{mg} / \mathrm{kg}$ /day $\mathrm{CdC} 1$ intraperitoneally for one week. Esophagus was removed and placed in $10 \%$ formaline. Sections were stained with Hematoxylene-Eosine and observed under light microscopy. Hyperplasia in the epithelium, an increase in fibrotic cells under epithelium, hemorrhage in vessels, free floating erythrocytes were all observed following fetal exposure. In conclusion and most importantly, cadmium chloride was found to cause an increase in connective tissue in esophagus mucosa.

KEY WORDS: Cadmium cloride; Oesephagus; Rat.

\section{INTRODUCTION}

Cadmium, a toxic heavy metal is an effective shortand lonCadmium a toxic heavy metal with short and long term effects particularly showing accumulation in organs as kidney, liver brain and testis. (Holt \& Webb, 1987). The dose dependent accumulation which has been demonstrated in studies, varied according to the application form Anderson and colleagues in their study in rats on the toxicity of cadmium chloride. When administered orally, cadmium chloride resulted in gastroenteritis caused by peristaltic movements (Andersen et al., 1988). Given orally, cadmium chloride is absorbed quickly in the lower side of oral mucosa and digestive tract mucosa (Sugawara \& Sugawara, 1991). At the same time, administered intraperitoneally in rats during pregnancy reaches the fetus through placental barrier leading to changes in the gastrointestinal tract (Goyer et al., 1992; Saillenfait et al., 1992). In addition, when given during lactation, to lactating mothers, and newborn pups, contents of cadmium chloride were found in the gastrointestinal canal (Saillenfait et al.). In experimental animals its application affected tissue, caused blood vessel hemorrhage and resulted in cellular degeneration (Frery et al., 1993). Administered intravenously to show teratogenic effects in pregnancy, hydrocephalus and microcephaly were reported as was a decline in body weight of the fetus (Nayak et al., 1989). Through the mouth and oral mucosa to the esophagus, cadmium chloride causes cellular degeneration affecting the vascular structure of the esophagus noting a continuing effect (Sugawara \& Sugawara). This study investigated the histopathological effect of cadmium chloride as a heavy metal on the esophageal cardiac region.

\section{MATERIAL AND METHOD}

Nine-week-old Wistar rats 180-200 g body weight were used in these trial and were divided in two groups of 24 animals each (control group and experimental group). The control group received $1 \mathrm{ml}$ of $0.9 \% \mathrm{NaCl}$ intraperitoneally every day for one week. Rats in the experimental group received $2 \mathrm{mg} / \mathrm{kg} /$ gun powdered cadmium chloride dissolved in water intraperitoneally every day for one week. All of the animals were individually housed in stainless steel cages at room temperature. Animals had free access to standard 
laboratory rat pellet and water ad libitum. Animals were sacrificed by decapitation under ether anesthesia, subsequently esophagus tissue was quickly removed. After fixation of tissue in $10 \%$ formaldehyde solution, samples were directly dehydrated in graded ethanol and embedded in paraffine. Thin sections of 5-6 micrometer were cut using a microtome and stained with Hematoxylene-Eosin (H-E) and examined using an Olympus BH2 light microscope.

\section{RESULTS}

Following intraperitoneal injection of cadmium chloride for 1 week, 4 hours after cadmium chloride administration a slowdown and recession was observed in the walking movements of the animal group. Histopathological changes in the esophagus were evaluated using different painting techniques. In the control group of rats cross sections of the surface epithelium showed cadmium, despite marked increase in keratinization.

Additionally connective tissue cells and fibers are sparse. There was no significant change in blood vessels (Fig. 1).

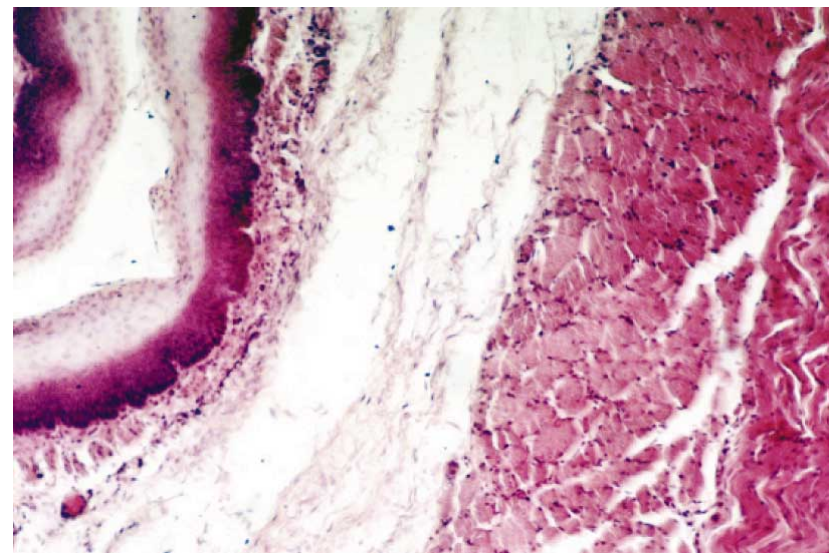

Fig. 1. Normal appearence of oesophagus. Hematoxylin-Eosin. $82 X$.

Basal layer epithelial cells of the esophagus into the lumen, irregularity, mild hyperplasia, and the surface epithelium cells in the normal rodent animals keratinization seen a more prominent increase in keratinization (Fig. 2).

A significant increase in mononuclear cell infiltration in the connective tissue under the epithelium, Dilatation and hemorhagia in blood vessels (Fig. 3).
Mucosa of the esophagus due to the toxic effects of cadmium chloride was one of the prominent structures in both lamina propria and submucosal layer of blood vessels congestion, hemorrhage, and freely distributed whereas erythrocytes (Fig. 4).

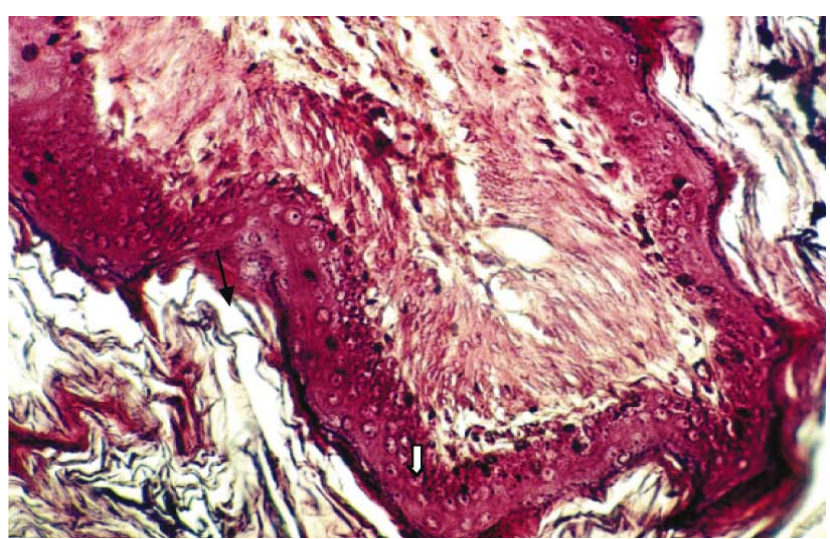

Fig. 2. A increase in keratinization and hypertropy in epithelium (arrows), Hematoxylen-Eosin. 82X.

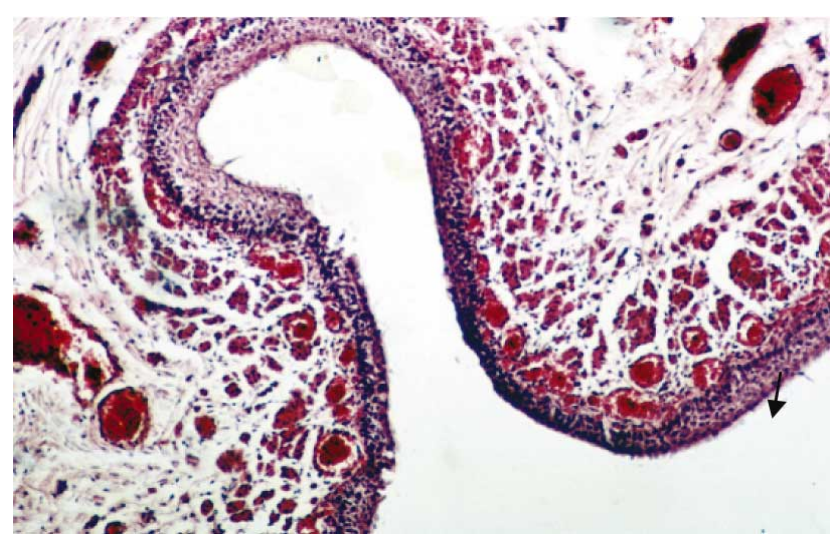

Fig. 3. Mononuclear cell infiltration in connective tissue. Dilatation and hemorhagia in blood vessels. Hematoxylin-Eosin. 41X.

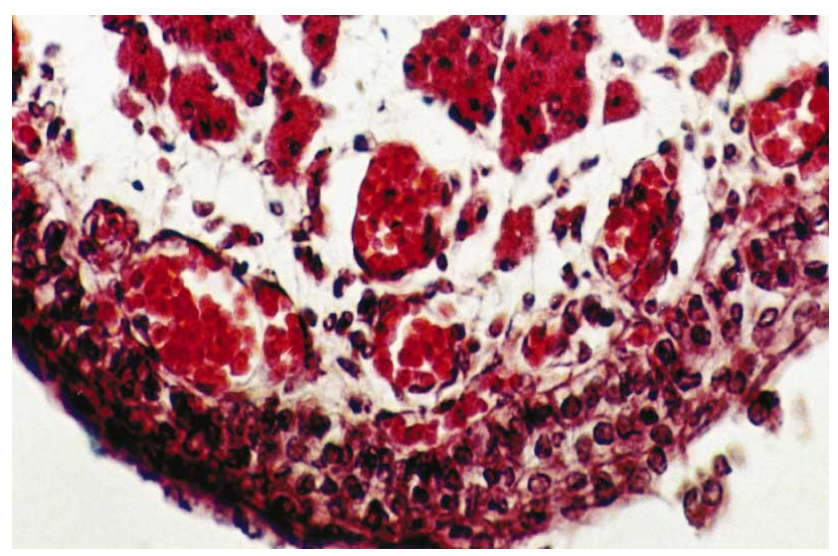

Fig. 4. Congestion in blood vessels and distributed freely in erythrocytes, Hematoxylin-Eosin. 82X. 


\section{DISCUSSION}

The toxic and teratogenic effects of cadmium chloride used in the industry are evidence of heavy metal content. (Andersen et al.; Sugawara \& Sugawara; Goyer et al.). Cadmium salts are frequently used in experimental studies. Applied cadmium has been shown to cause toxic gastroenteritis, (Sugawara \& Sugawara). Parenteral liver necrosis, and renal lesions affecting especially liver and kidney, with systemic circulation including testis, heart spleen, pancreas and digestive system were reported. In our study esophageal epithelial cells, connective tissue cells, vascular structures and mucosa sustained cadmium chloride effect depending on degenerative changes observed. (Figs.1 and 2). Tanhan et al., (2005), carried out their study, 96 hours and cadmium piknosis nuclei of epithelial cells and in snail oesophagus cell dilatation was observed. Basal lamina thickening, mucus secreting cells indicated an increase and muscle sheath lying underneath the epithelium was also found to be damaged by cadmium. There are studies on the effects of cadmium chloride on the digestive system as well as effect on secretion of the channels of absorption (Sugawara \& Sugawara; Saillenfait et at.).

In the present experimental study depending on the effect of cadmium esophageal cardiac fibrous tissue growth, congestion and hemorrhage of blood vessels and histological changes were found in cells. We also observed epithelial cell and connective tissue changes in inflammatory cell infiltration. Significant changes were recorded in dilatation of blood vessels and hemorrhage. As a result various parts of the digestive system cadmium chloride channel identified in previous studies on the effects of biochemical and histological changes in the physiological effects caused in the esophageal cardiac region by cadmium.

DEVECI, E. \& DEVECI, S. Efecto del cloruro de cadmio sobre el esófago de ratas. Int. J. Morphol., 29(3):678-680, 2011.

RESUMEN: El cloruro de cadmio $\left(\mathrm{CdCl}_{2}\right)$ es una sustancia teratogénica utilizada en la industria. Aunque es conocido por causar toxicidad en testículos, riñones, corazón e hígado, pocos estudios se han realizado en el sistema digestivo. Se estudió el efecto del CdCl ${ }_{2}$ en el esófago de ratas. Fueron utilizadas 24 ratas Wistar albinas de180-200 g. Los animales fueron divididos en dos grupos: a un grupo se le administró $2 \mathrm{mg} / \mathrm{kg} /$ día de $\mathrm{CdCl}_{2}$ vía intraperitoneal durante una semana, y un grupo control. Luego, el esófago fue extraído y fijado en formalina al $10 \%$. Las secciones fueron teñidas con H-E, examinándose al microscopio óptico. Se observó después de la exposición fetal, hiperplasia epitelial, con un aumento en las células fibróticas en el epitelio y hemorragia en los vasos sin eritrocitos flotantes. Es importante destacar que el cloruro de cadmio causó incremento en el tejido fibroso de la mucosa esofágica.

PALABRAS CLAVE: Cloruro de cadmio; Esófago; Rata.

\section{REFERENCES}

Andersen, O.; Nielsen, J. B. \& Svendsen, P. Oral cadmium chloride intoxication in mice: effects of dose on tissue damage, intestinal absorption and relative organ distribution. Toxicology, 48(3):225-36, 1988.

Fréry, N.; Nessmann, C.; Girard, F.; Lafond, J.; Moreau, T.; Blot, P.; Lellouch, J.\& Huel, G. Environmental exposure to cadmium and human birthweight. Toxicology, 79(2):109$18,1993$.

Goyer, R. A.; Haust, M. D. \& Cherian, M. G. Cellular localization of metallothionein in human term placenta. Placenta, 13(4):349-55, 1992.

Holt, D. \& Webb, M. Teratogenicity of ionic cadmium in the Wistar rat. Arch. Toxicol., 59(6):443-7, 1987.

Nayak, B. N.; Ray, M.; Persaud, T. V. \& Nigli, M. Embryotoxicity and in vivo cytogenetic changes following maternal exposure to cadmium chloride in mice. Exp. Pathol., 36(2):75-80, 1989.

Saillenfait, A. M.; Payan, J. P.; Ban, M. \& de Ceaurriz, J. Indirect and lactation-associated changes in renal alkaline phosphatase of newborn rats prenatally exposed to cadmium chloride. J. Appl. Toxicol., 12(3):205-10, 1992.

Sugawara, N. \& Sugawara, C. Gastrointestinal absorption of Cd-metallothionein and cadmium chloride in mice. Arch. Toxicol., 65(8):689-92, 1991.

Tanhan, P.; Sretarugsa, P.; Pokethitiyook, P.; Kruatrachue, M. \& Upatham, E. S. Histopathological alterations in the edible snail, Babylonia areolata (spotted babylon), in acute and subchronic cadmium poisoning. Environ. Toxicol., 20(2):142-9, 2005.

\section{Corespondence to: Engin Deveci \\ Dicle University \\ Medical Faculty \\ Histology and Embryology \\ Dept. 21280 Diyarbakır \\ TURKEY}

Received: 14-04-2011

Accepted: 06-06-2011

Email: engindeveci64@gmail.com 